(C) 2014

Писаренко П. В., доктор сільськогосподарських наук, професор, Диченко О. Ю., стариий викладач

Полтавська державна аграрна академія

\title{
ОДНОЧАСНІСТЬ (СИНХРОННІСТЬ) ЗМІНИ ДИНАМІКИ ШКІДНИКІВ БУРЯКІВ ЦУКРОВИХ У ЦЕНТРАЛЬНОМУ ЛІСОСТЕПУ УКРАЇНИ
}

\section{Рецензент - доктор сільськогосподарських наук, професор В. М. Писаренко}

\begin{abstract}
Наведені дані щзодо одночасності масових розмножень багатьох видів шкідливих комах, у тому числі деяких шкідників буряків иукрових у центральному Лісостепу Украӥни. Підтверджено, щчо для прогнозування початку чергових популяиійних ичиклів совки озимої, совки-гамма, совки капустяної, метелика лучного й довгоносика бурякового звичайного дочільно використовувати роки різких змін сонячної активності. Встановлено, щзо початок чергових масових розмножень названих шкідників у центральному Лiсостепу Украӥни відбувався в 90-93 \% проаналізованих випадків, щзо дає змогу передбачити тенденції масового їх розмноження у майбутньому.
\end{abstract}

Ключові слова: одночасність, икідники, буряки иукрові, зміна динаміки, масові розмноження, иентральний Лісостеп України, сонячна активність, фази динаміки сонячної активності.

Постановка проблеми. Серед шкідників буряків цукрових комахам належить провідне місце. Вони постійно або циклічно шкодять бурякам цукровим у різних природно-кліматичних зонах України. Небезпечними серед них є лучний метелик, звичайний буряковий довгоносик, в окремі роки - багатоїдні совки, а саме: совка озима, совка-гамма, совка капустяна. Для згаданих шкідників буряків цукрових відома багаторічна статистика масових розмножень.

Проблема динаміки популяцій упродовж тривалого часу залишається центральною проблемою в екологічних дослідженнях багатьох країн світу. Особливо актуальними є дослідження екологічних закономірностей динаміки популяцій як основи біологічного (екологічного) прогнозування.

Аналіз основних досліджень і публікацій, у яких започатковано розв'язання проблеми. Огляд видового складу й екології комах, що шкодять бурякам цукровим, вперше опублікував Ф. П. Кеппен, а у 1881 році обгрунтував концепцію про фактори, що впливають на динаміку популяцій шкідливих комах [4].

У 1925 році В. Г. Аверін [1] переконливо довів повторюваність масових розмножень у часі важливих шкідників України. Гросгейм О. О. масові розмноження шкідливих комах розглядав як центральну проблему розвитку біосфери (B. I. Вернадського), а циклічність (періодичність) як основу цього прогнозування спалахів чисельності шкідливих комах.

У кінці 30-х р. ХХ століття українські екологи провели фундаментальні теоретичні дослідження популяційної динаміки шкідливих комах, за результатами яких у 1938 році була опублікована колективна монографія [3]. У названій роботі було уперше здійснено теоретичний синтез досягнень вітчизняних й іноземних екологів у галузі популяційної динаміки тварин, у тому числі шкідливих комах і закономірностей їх масових розмножень. Четвертий розділ цієї монографії призначено періодичності градацій та їх можливої залежності від багаторічної динаміки сонячних плям (сонячної активності, або «космічної погоди» за - О. Л. Чижевським).

Узагальнення й аналіз теоретичних уявлень про динаміку популяцій комах виконав Г. О. Вікторов [2]. На його думку, коливання чисельності комах визначається взаємодією двох принципово різних процесів: модифікації та регуляції. 3 них модифікація обумовлена дією випадково мінливих чинників зовнішнього середовища (абіотичні), а регуляція - чинниками, чисельність яких змінюється у відповідності до коливань чисельності регульованої популяції [2].

Метою наших досліджень було обгрунтування зміни динаміки шкідників буряків цукрових у центральному Лісостепу України.

Завдання досліджень: виконати історикостатистичний аналіз масових розмножень шкідливих комах, у тому числі шкідників буряків цукрових (совки: озима, гамма, капустяна, метелик лучний i довгоносик буряковий звичайний) та визначити закономірності зміни динаміки популяцій названих шкідників буряків цукрових.

Матеріали і методи досліджень. Для уточнення видового складу шкідників буряків цукрових використовували польовий (статистичний та маршрутний) метод досліджень; для визначення екологічних закономірностей динаміки популя- 


\section{СІЛЬСЬКЕ ГОСПОДАРСТВО. РОСЛИННИЦТВО}

ції шкідників буряків цукрових - історикостатистичний та аналого-історичний методи.

Результати досліджень. Особливо показові масові розмноження в центральному Лісостепу України відбувалися в період 1868-2012 рр., коли одночасно в масі з'являлося від 20 до 40 видів шкідників, у тому числі шкідників буряків цукрових (совки: озима, гамма, капустяна, метелик лучний і довгоносик буряковий звичайний).

1868-1870 pp. - 28 видів, включаючи совку озиму, совку-гамма, совку капустяну, метелика лучного, довгоносика бурякового звичайного;

1878-1880 pp. - 34 види, в тому числі совка озима, совка-гамма, совка капустяна, метелик лучний, довгоносик буряковий звичайний;

1890-1896 pp. - 40 видів, у тому числі совка озима, совка-гамма, совка капустяна, метелик лучний, довгоносик буряковий звичайний;

1910-1914 pp. - 32 види, в тому числі совка озима, совка-гамма, совка конюшинна, совка капустяна, метелик лучний, довгоносик буряковий звичайний;

1923-1929 pp. - 35 видів, включаючи совку озиму, совку-гамма, совку капустяну, совку конюшинну, метелика лучного, довгоносика бурякового звичайного.

У 1928 р. на півдні Правобережної України на буряках цукрових одночасно в масі 3'явилися конюшина й капустяна совки, тому, пошкодження метелика лучного були замасковані передусім шкідливістю названих видів. Ці шкідники в 1928 р. охопили весь район Правобережної України. Відомо, що в 1929 р. одночасно з метеликом лучним буряки сильно пошкодив буряковий клоп у Полтавській, Сумській і Харківській областях. Вважають, що він сумісно із метеликом лучним був причиною загибелі цієї культури на великій площі [6].

1934-1942 pp. - одночасно розмножилося 32 види шкідливих комах, у тому числі совка озима, совка-гамма, совка конюшинна, совка капустяна, метелик лучний, довгоносик буряковий звичайний;

1956-1960 pp. - 34 види, в тому числі совка озима, совка-гамма, совка капустяна, метелик лучний, довгоносик буряковий звичайний;

1964-1968 pp. - 40 видів, у тому числі совка озима, совка-гамма, метелик лучний, довгоносик буряковий звичайний;

1972-1977 pр. - 33 види, у тому числі совка озима, совка-гамма, метелик лучний, довгоносик буряковий звичайний;

1986-1988 pр. - 22 види, у тому числі совкагамма, совка капустяна, метелик лучний, довгоносик буряковий звичайний;

2000-2012 pр. - 22 види шкідливих комах, у тому числі совка озима, совка-гамма, совка капустяна, метелик лучний, довгоносик буряковий звичайний.

Виходячи 3 наведених даних, одночасність масових розмножень багатьох видів шкідливих комах, зокрема й окремих шкідників буряків цукрових на значній території не можна пояснити лише зміна метеорологічних чинників; малоймовірна їх зміна одночасно в різних природногеографічних регіонах. У останні роки дослідники сонячно-земних i сонячно-біосферних зв'язків переконливо довели, що головним синхронізатором популяційних, кліматичних і трофічних циклів $\epsilon$ сонячна активність, але для прогнозування початку популяційних циклів використовувати в якості критерію показники мінімуму, максимуму, гілок піднесення та спаду сонячної активності не рекомендується, оскільки ймовірність справдженості таких прогнозів невелика. Нами також підтверджено це положення на прикладі масових розмножень деяких шкідників буряків цукрових у центральному Лісостепу України (табл. 1).

\section{1. Розподіл масових розмножень деяких икідників буряків цукрових у центральному Лісостепу Украӥни по фазах динаміки СА}

\begin{tabular}{|c|c|c|c|c|}
\hline \multirow{2}{*}{ Назва шкідника } & \multicolumn{5}{|c|}{ Розподіл початку чергових масових розмножень по фазах сонячних циклів, \% } \\
\cline { 2 - 5 } & мінімум СА & гілка піднесення СА & максимум СА & гілка спаду СА \\
\hline Совка озима & 19,0 & 38,0 & 5,0 & 38,0 \\
\hline Совка-гамма & 13,0 & 20,0 & 14,0 & 53,0 \\
\hline Совка капустяна & 44,0 & 10,0 & 10,0 & 36,0 \\
\hline Метелик лучний & 0,0 & 49,0 & 21,0 & 30,0 \\
\hline $\begin{array}{c}\text { Довгоносик } \\
\text { буряковий } \\
\text { звичайний }\end{array}$ & 11,0 & 28,0 & 17,0 & 44,0 \\
\hline
\end{tabular}


СІЛЬСЬКЕ ГОСПОДАРСТВО. РОСЛИННИЦТВО

\section{2. Масові розмноження деяких икідників буряків цукрових у центральному Лісостепу України та різкі зміни сонячної активності (СА)}

\begin{tabular}{|c|c|c|c|}
\hline \multirow{2}{*}{ Назва шкідника } & \multirow{2}{*}{$\begin{array}{c}\text { Роки масових } \\
\text { розмножень }\end{array}$} & \multicolumn{2}{|c|}{ Початок чергових масових розмножень, \% } \\
\cline { 3 - 4 } & $1813-2007$ & $\begin{array}{c}\text { у роки різких } \\
\text { змінень СА }\end{array}$ & через 1 рік після реперу \\
\hline Совка озима & $1829-2007$ & 90 & 10 \\
\hline Совка-гамма & $1871-2000$ & 93 & 7 \\
\hline Совка капустяна & $1855-2011$ & 91 & 7 \\
\hline Метелик лучний & $1851-2000$ & 93 & 10 \\
\hline $\begin{array}{c}\text { Довгоносик буряковий } \\
\text { звичайний }\end{array}$ & & 90 & \\
\hline
\end{tabular}

В останні роки 3 проблеми прогнозування процесів та явищ у біосфері й агроценозах виконані фундаментальні дослідження екологів, ентомологів, геофізиків, кліматологів та гідрологів. Результати досліджень підтвердили, що надійним критерієм для прогнозування початку чергових популяційних циклів тварин, у тому числі комах, є сонячна активність та іiі земні прояви, тобто взаємодія й синхронізація з кліматичними i трофічними циклами. Проте враховуючи, що сонячні плями самі по собі не є найбільш істотною характеристикою сонячної активності

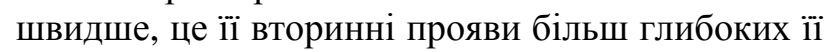
процесів, свого часу було рекомендовано використовувати іï різкі зміни в 11-ти річних сонячних циклах, тобто так званих роках сонячних реперів.

Ми здійснили історико-статистичний аналіз початку чергових популяційних циклів совки озимої, совки-гамми, совки капустяної, лучного метелика і довгоносика бурякового звичайного в роки різких змін сонячної активності (табл. 2).

Як видно 3 даних таблиці 2, переважна біль-

\section{БІБЛІОГРАФІЯ}

1. Аверин В. Г. О луговом мотыльке (Eurycreon sticticalis) // Бюллетень о вредителях сельского хозяйства и мерах борьбы с ними. - Харьков, 1914. - № 3. - C. 15-16.

2. Викторов Г. А. Проблемы динамики численности насекомых (на примере вредной черепашки) / Викторов Г. А. - М. : Наука, 1967. $271 \mathrm{c}$.

3. Іванов С. П. Масові розмноження тварин i теорії градацій / Іванов С. П., Левітт М. М., Смчук М. М. - К. : Вид-во АН УРСР, 1938. - 252 с.

4. Кеппен Ф. О. О саранче и других прямокрылых из семейства Acridiodea, преимущест- шість масових розмножень вказаних шкідників буряків цукрових у центральному Лісостепу України починалася саме в роки різких змін сонячної активності (90-93 \%) і лише 7-10 \% їх через рік після. А це свідчить про доцільність використовувати даний критерій для прогнозування початку чергових популяційних циклів. Відомо, що всі прогнози, розроблені з урахуванням різких змін сонячної активності в Україні, справдилися.

Висновки: 1. Підтверджено, що для прогнозування початку чергових популяційних циклів совки озимої, совки-гамма, совки капустяної, метелика лучного і довгоносика бурякового звичайного доцільно використовувати роки різких змін сонячної активності, які були запропоновані у 1985 році [5].

2. Згідно 3 нашими даними, початок чергових масових розмножень названих шкідників у центральному Лісостепу України відбулося в 90$93 \%$ проаналізованих випадків, що дає змогу для передбачення тенденції масового їх розмноження в майбутньому.

венно по отношению России / Ф. О. Кеппен // Тр. русск. энтомол. об-ва. - 1870. - Т. 5. - С. $1-$ 352.

5. Павлов Б. К. Методология прогнозирования численности животных / Б. К. Павло // Прогнозирование экологических процессов. - Новосибирск : Наука СО, 1986. - С. 185-190.

6. Пузырный Р. Г. Луговой мотылек в Харьковском отделении Союзсахара в 19929 году / Р. Г. Пузырный// Луговой мотылек в 19281930 гг. / Сб. материалов и статей по биологии лугового мотылька и борьбе с ним. - К. : Изд-во УНИСа, 1932. - Кн. 2. - С. 191-238. 